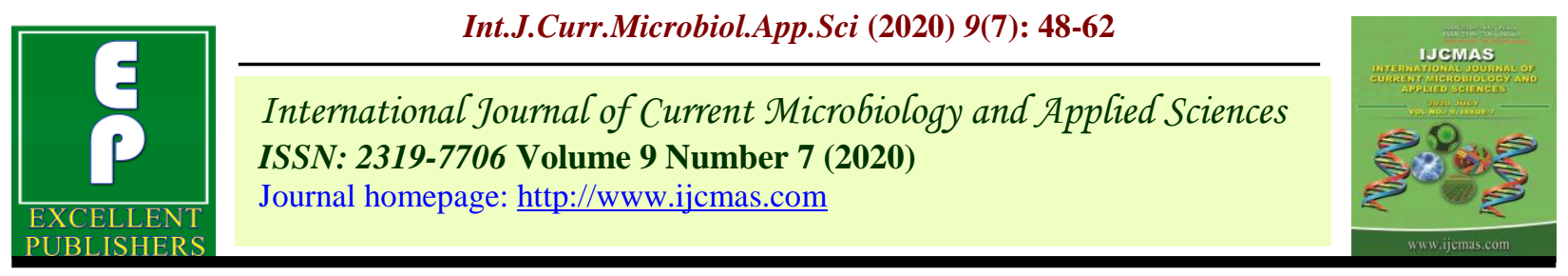

Original Research Article

https://doi.org/10.20546/ijcmas.2020.907.006

\title{
Diversity of Wild Medicinal Flora in Lahaul Valley of Himachal Pradesh, India
}

\author{
Antul Kumar*, Anuj Choudhary and Harmanjot Kaur \\ Department of Botany, College of Basic Sciences and Humanities, Punjab Agricultural \\ University, Ludhiana-141004, Punjab, India \\ *Corresponding author
}

\begin{tabular}{|l|}
\hline Ke y w o r d s \\
Himalayas, \\
Vegetation, \\
Biodiversity, \\
Hot spots, \\
Desert, Climate \\
\hline Article Info \\
\hline Accepted: \\
05 June 2020 \\
Available Online: \\
10 July 2020 \\
\hline
\end{tabular}

\section{A B S T R A C T}

Traditional medicinal system utilizes a huge scale of plants which are largely angiosperms. The high altitude cold deserts of the Indian Himalayas sustain a considerable amount of specialized vegetation, which is widely scattered across different habitats. The cold desert covers land area of 186,200 square $\mathrm{km}$ spread over region of the Himalayas. These desert covers about $20 \%$ of total land of earth, but the pattern of precipitation and altitude of cold desert specifically supports a unique biome. The lahaul valley is rich in local medicinal herbs of immense potentials and practicnors of Tibbetian or Buddhist community. These biodiversity hot spots are a treasure of medicinally important plants. Overall 31 medicinal plants were recorded from forested and moist shady habitats were evaluated whereas, these populations categorized under threatened categories. Mostly species are not commercially viable but notification from the study ensures ecological rich areas, ex-situ conservation and large scale cultivation strategies of the medicinal plants. Despite toughness of climate in this region, it provides diversity in flora that showed richness valued as medicinal plant.

\section{Introduction}

Man has been using medicinal plants as a major source of therapeutic agents since Vedic periods. Himalayas are specific and largest mountain chains that cover roughly $10 \%$ of total land surface of India. The varied climate and unique environmental conditions support a diverse and unique flora. These areas are a home and important habitat of more than 9,000 plant species, mainly angiosperms, out of which about 3,470 are considered exclusively endemic to this region, and hence it is regarded as the major hot spot of biodiversity. Indian cold deserts come under the Trans-Himalayan biological zone and constitute major parts of Himalayas (Aswal and Mehrotra, 1994). Lahaul valley is 
dominated by annual and perennial plants, a few stunted shrubs and bushes and falls under high alpine regions. The vegetative growth starts during summer when the snow starts melting providing abundant moisture. The flowering season initiates during the end of August and senescence begins by the end of September. The mountain slopes, meadows and alpine pasturelands give a spectacular display of flowers of cold desert barren mountains. The vegetation pattern within Lahaul valley is specific in different locations like Keylong, Rohtang pass, Koksar and Piyukar that lie along the major river Bhaga. The total geographical area under cold deserts in Lahaul spiti is about 11,000 square $\mathrm{km}$, out of which 3,400 sq. kmlies in Lahaul itself. The alpine meadows mountain slopes and alpine pasturelands give a spectacular display of flowers to the cold desert barren mountains (Ballabh et al., 2008; Chaurasia and Singh, 2001). The survival of plant species especially in temperate region is under threat by intensified pressure of harsh environmental conditions and herbivores which cause its depletion. Low oxygen and carbon levels with large variation in seasonal temperature, and very long freezing winters of 5 to 7 months (November-April) are other challenges. The precipitation is either very low. During winters snow is the most common form of precipitation. To tolerate such extreme environmental condition, plants initiate the biosynthesis of specific chemical compounds that help plants to overcome these conditions (Table 2). These adaptive biochemical changes help in managing the physical challenges and phases during their life cycle. The collected data may be interest to initiatives aimed at fostering sustainable rural development in an area that faces serious economic problems, widespread illiteracy, and isolation. The validity assessment from the present research provides the potential to identify, and use plants and their ingredients most significant for their pharmacological properties. The findings of this study also advocate the prerequisite for broad transdisciplinary scrutinizes aimed to confirm the active conservation of valuable indigenous knowledge as well as plant distribution in Indian mountain ranges. Maximum number of plants species recorded during survey are of economic use in these regions belonging to families Apiaceae, Asteraceae, Rosaceae, Scrophulaiaceae, Gentianaceae and Polygonaceae (Figure 1). The common species grown in these regions are Rosa webbiana, Jurinea, Picrorhiza kurroa, Verbascum thapsas, Mentha longifolia, Sedum ewersii, Carum carvi, Ephedra gerardiana, Rhododendron campanulatum, Bistoria vivipara (Figure 3) (Table 2).

\section{Lahaul and Amchi medicinal system}

The word 'Lahaul' presumably composed of two Tibetan words 'Lah and yul, means "the land of Gods. According to its demographic composition, it is also called "as Valley of Glaciers". Bara shigri, Chhota shigri, Gangstang, Sonapani or the land surrounded by passes. The two passes are highlighted: Kunzam pass and Rohtang pass. The Kunzam pass separates the Lahaul valley from Spiti and Rohtang pass separates the valley from Kullu and is marked as the gateway for Lahaul (Kala, 2005; Kanta and Sheikh, 2018). The climate of the district is harsh and shows a remarkable variation. During winter, heavy snowfall covers the entire district and forms blanket of snow and the climatic conditions are very similar to arctic conditions (Table2). The trans-Himalayan areas are cut off from adjoining Himalayas starting from midOctober to the mid of April and this period is considered as winter period, thus regarded as cold deserts (Kaul, 1997; Adhikari et al., 2016). Most of the communities follow Buddhist religion and population is broadly Buddhist who worships in sacred ghomphas. The Amachi system is practiced in most of 
the region in Lahaul. It is very effective in meeting the health care needs of this region. This medicine system flourished in the Himalayan region due to the lack of allopathic treatments. More than $60 \%$ health issues of tribal communities totally depend upon natural resources collected from plants and still looked after by the Amchis (Kumar et al., 2013; Nautiyal et al., 2001; Chandrasekar and Srivastava, 2009).

\section{Materials and Methods}

\section{Area surveyed and collection}

The wide range of Lahaul valley surveyed during 2017-2018. The field survey was conducted during May to September, the information was collected on the basis of different plant parts. The information on folk uses was collected from Buddhist monk of different Gompas, Amachis, tribal communities, local peoples and literature. Information on folk uses and identification of samples was also done with the help of indigenous Lahaolis people. The survey periods were selected on the basis of flowering seasons so that maximum information could be documented. The famous monasteries or gompas of the areas visited such as Kardang, Piyukar, Parandas, Nemafed, Bondla, Ishtingri, Guru Ghantal, Kungri and sissur. The species were collected from altitude range from $3080 \mathrm{~m}$ to $3500 \mathrm{~m}$. The sites were fall in the range of $32.5417^{\circ} \mathrm{N}$ to $32.57938^{\circ} \mathrm{N}$ and $77.0177^{\circ} \mathrm{E}$ to $77.0514^{\circ} \mathrm{E}$ (Table 1). The 'Lamas' of these monasteries are spiritual and follow Bhuddish and give religious training to their followers about beautiful murals, localities, indigenous flora and golden images of Padmasambhava. The floristic diversity was assessed on the basis of medicinal aspects used for the local herbal formulations prepared by amchis.

Information provided on the basis of field visits with amchis, will be verified with the literature provided by earlier visits of ethanobotanists. The information on pharmacological uses, phytochemical and conservation status of medicinal plants has been taken from different publication regarding survey on Western Himalayas in order to support the literature on uses of medicinal plants. The specimen identification was done with the help of existed flora on cold desert published by Botanical survey of India (Chaurasia and Singh, 2001; Kala, 2005; Kumar et al., 2013).

\section{Description of selected medicinal plant}

Achillea millefolium belongs to the family Asteraceae. It is commonly found along road sides and dry places. The Flowering occurs during the month July to September depending upon the habitat. This perennial herb has a branched stem. Flower head is terminal, corymbose with white short pedicel. It's an herb with rhizome, whitish, slender, entangled hairs, erect, branched only at the inflorescence. Leaves are narrowly oblong and lanceolate. Basal leaves 10-20 cm long, 1-2 cm wide; cauline leaves smaller, sessile, lanceolate, two to three times pinnatisecte; linear and acute segments not more than 3 $\mathrm{mm}$ in width, closely arranged. Heads, with 2-5 $\mathrm{mm}$ long peduncles, form a dense corymb, like a brush. Ligulate flowers usually purple, sometimes white. Disk flowers are yellow. The major chemical constituent is 'Achilleine'. This leaf extract is useful in urinary problem and toothache. It acts as a stimulant, tonic, diaphoretic, treatment for cold and colic.

Aconitum violaceum belongs to family Ranunculaceae. The plants are frequently distributed in open rocky slope preferring sub alpine meadows. Flowering occurs in month of July to mid-August. It is a perennial herb having 10-30 $\mathrm{cm}$ height, unbranched or may be rarely branched stems with pubescence on apical portions. Roots are tuberous in nature. 
The petioles of leaves vary in size. Its size ranges from 5-10 $\mathrm{cm}$ across depending upon the position. The lower leaves are smaller than upper and leaf blades are typically deeply rounded. Inflorescence is simple, raceme but nearly dense in appearance. Inflorescence posse's hairy sepals dominated with violet colour but having yellowish or blue veins. The blue veins are clearly visible to naked eyes. Petals bearing nectar-secreting spur with re-curved lips. Seeds are numerous. The major chemical constituent is aconitine. It used as a nervine and pleasant tonic. It is used in cough, gastrointestinal complaints and rheumatism. Fresh root powder is taken with hot water in fever due to cure bad cold. Dried root pieces are fitted in tooth cavities against toothache. It is used for curing cough, cold and stomachache in infants.

Anaphalis triplinervis belongs to family Asteraceae. It is widely distributed in slopy grasslands and preferred moist habitat along the waterfall. The flowering occurs in month of June to August. The plant grows up to 25 $30 \mathrm{~cm}$ in height and not completely erect but provide zigzag appearance. The wooly leaves are $4-8 \mathrm{~cm}$, lanceolate and somewhat narrow at apex. The most common key for identification of species is that in majority, there are three veins, but may be five veins. The flowers are present in clustered with dome shape and possess corymb type inflorescence. The yellow or reddish colour present on central disc of flower covered by white petal appears a neck or circular ring around the central florets. The major chemical constituents are the derivatives of guaiene, muurolene, cadinene and anaphatol. It is used in the treatment of wounds, chronic diseases, genital problems and eyes diseases.

Astragalus candoleanus belongs to family Fabaceae. The plant prefers dry habitat and barren rocky mountain. The reproductive cycle occurs early in month of June to
August. It's a stem less perennial herb to sub shrub, hairy; leaves pinnate, compound with up to 28 pairs of leaflets, latter elliptic to oblong, up to $2 \mathrm{~cm}$ long, hairy especially beneath; stipules up to $15 \mathrm{~mm}$ long with ciliate margin; flowers yellow, 3-5-flowered dense raceme, peduncle almost absent to $5 \mathrm{~cm}$ long; bracts linear; calyx up to $15 \mathrm{~mm}$ long with $5-8 \mathrm{~mm}$ long teeth; corolla up to $2.5 \mathrm{~cm}$ long; pod up to $2 \mathrm{~cm}$ long, densely silky. The major chemical constituents are asparagines. It is used for the ailment of abdominal complaints, leucorrhoea, aphrodisiac and diabetes.

Belenia praealta belongs to family solanaceae. The plant is commonly found along the barren dry land. The plants are 30$60 \mathrm{~cm}$ tall. Roots are small and well differentiated. The stems are highly branched, secretary or hairy in nature. Petiole is $1-6 \mathrm{~cm}$ long, leaf blade ovate-elliptic, ovate-deltate, 3-8 cm, with base cuneate, truncate in shape, obtuse or acute apex. Paniculate inflorescence, yellow with purple veins, unequal stamens, exerted; anthers are 2-3 $\mathrm{mm}$. long style exerted with thick fruiting calyx. The major chemical constituents are hyoscyamine and hyoscine. It is used for the treatment of ulcers, hepatic disorders, boils and epilepsy.

Bistorta vivipara belongs to family Polygonaceae. It is commonly found in moist hill slopes and meadows, larch forests and their fringes in sub alpine region. Flowering occurs during July to August. It is small herb of $10-15 \mathrm{~cm}$ height with dense inflorescence, oblong or linear leaves, long petiole of $6-9 \mathrm{~cm}$ length bearing clustered of flowers that appear white in early stages but turn into deep red with aging. Seeds are viviparous in nature. The major metabolites isolated are quercetin, chlorogenic acids and kaempferol. It is used for treatment of wounds, diarrhea cough and promotes expectoration. 
Carum carvi belongs to family Apiaceae. It mostly prefers wet or dry waste fields, grasslands and sides of cultivated fields. Reproductive cycle occurs during July to September. The plant is annual in nature with glabrous erect stem that attains height of 30$60 \mathrm{~cm}$. The leaves are not in proper symmetry, may be either directed or linear. The inflorescence is umbel type. The major chemical constituents are ketone, carvone, terpene and traces of carvacrol, carvoneisodihydrocarvone, dihydrocarvacrol, carveol, scopoletin, gerniarin. It is used as anthelmintic, carminative, stimulant, stomachic, antispasmodic pain and to cure indigestion gastric troubles.

Chenopodium foliosum belongs to family chenopodiaceae. It is found in dry regions of cultivated areas. Reproductive phase occurs from May-October. This annual herb is 25-90 cm tall with dense stalk; leaves are dissected, typically pointed and triangular in symmetry. The branches are spreading, yellowish to green. Bracts are lanceolate. Leaf blade with hastate base, fairly succulent, fruits are somewhat sweet and born in a cluster at each node with dark red cherry like colour on ripening. The major chemical constituents are gomphrenol derivatives (Patuletin and spinacetin). These swine's berries act as immuno stimulant, antioxidant and has been used as decoct for treatment of cancer.

Cuscuta europaea belongs to family Cuscutaceae. It is parasitic threadlike vine attached on others plants. Flowering occurs in month of July- mid August. It is an annual stem parasitic plant and completely lack roots. The plant stem lacks chlorophyll and appears yellow, pinkish or may be bright red in colour. The leaves are minute and reduced to scales which twins around the stem of suitable host. The hermaphrodite flowers are present and often pink or white in colour. The major chemical constituents are dulicitol, propenamides, reflexin and astragalin. It is effective against the microbial infection, chemoprotective, antiprotozoal and renal disorders.

Ephedra gerardiana belongs to family Ephedraceae. It is found in dry areas, along road sides and lower foot hills. Flowering occurs from July to September. The shrub is hard, erect, green, branched with needle shapes leaves having $20-30 \mathrm{~cm}$ tall. Branches are scaly on joints. Fruit is not truly round, but appears ovoid in shape red with fleshy bracts. Fruit bears 2 black colored seeds. The major chemical constituents are ephedrine and it is used to stimulate brain, increases heart beat and increases body heat.

Euphrasia officinalis belongs to family Scrophulariaceae. It is commonly found in moist damp areas, unused and damp areas. Reproductive phase occurs during July to September. An annual small herb having 40 cms height with wiry branched stem. Leaves appear saw-toothed or ovate in shape. Flowers are typically small, white and purple tinged, 2-lipped flower with yellow throats or lilac with purple vein, borne in terminal spike clusters. The major chemical constituents are choline and phytosterols like beta-sitosterol and stigmasterol. It is used in treatment of conjunctivitis or others eyes disorders.

Gentiana barbata belongs to family Gentianaceae. It commonly occurs in alpine meadows along the river side, moist places, brook banks and forest fringes. Reproductive cycle occurs during June to September. These are small and erect annual or biennial herbs. The plant attains $20-40 \mathrm{~cm}$ height, simple and typically branched slightly at the top. Leaves are radical, little wider than cauline ones, which are lanceolate or linear in shape. The flowers are 5-6 cm long, three in number, quadrimerous at the tip of stem. The major chemical constituents are gentiacochianin, 
diosmetin, decussating, apigenin etc. It is bitter to taste and the potency is cool and blunt. It is used for the disorders of bile, inflamed wounds, and chronic liver disease.

Krascheninnikovia ceratoides belongs to family Chenopodiaceae. Its distribution is frequent on moist typically alpine slopes. Flowering season occurs during JulySeptember. The erect or decumbent plant is $30-90 \mathrm{~cm}$ tall, hoary with stellately hairy, woody, dense herb or under shrub. Leaves are small, 1.2-3.8 cm long, linear or lanceolate, oblong with re-curved margins. The leaves are sessile and shortly petiolated. The unisexual flowers are minute in size, born axillary in cluster and forming pointed ends towards the ends of the branches. The fruiting bracts crowded along the upper parts of the branches with silky rusty-brown, $0.8 \mathrm{~cm}$ long hairs. The sepals 4, petals are absent and stamens are 4, stigma 2, filiform, ovary compressed and enclosed in a hard capsule which is hidden by silky grey hairs. It is used for the treatment of respiratory disorders.

Origanum vulgare belong to family Lamiaceae. It is commonly found in grassy regions, slopes and dry uncultivated areas. Reproductive phase occurs during July to September. The perennial herb is also known as white clover. The leaves are aromatic with sweet fragrance, oval in shape. The dark purple buds at the top of the stem open to show purple, pink or occasionally white bunches of thyme like flowers. The major chemical constituents are protocatechuic acid ester derivatives, origanol $\mathrm{A}$ and origanol $\mathrm{B}$ along with ursolic acid, oleanolic acid, $\beta$ sitosterol, and triacontanol. It is used for the treatment of cancer and sexual sterility.

Oxyria digyna belongs to family Polygonaceae. It attains a height of $10-20 \mathrm{~cm}$ with dense tuft leaves on leaves. Reproductive cycle occurs from Jun to August. The pigmentation varies as dark green to reddish. The branches arise from base of stem, are fleshy or spongy with long stalk with bean shaped leaves slightly curved at apex, arranged in pairs on stems with $2.5-10 \mathrm{~mm}$ in length blade with 5-7 veins in number. The major chemical constituents are oxyria, flavonol, vitexin, hesperedin, and stigmasterol. The leaves and inflorescence are edible and beneficial in treatment of scurvey and dysentery.

Parnassia nubicola belongs to family Parnassiaceae. It is distributed in moist grassland fringes and watersides along the roadside. Reproductive cycle occurs during month of July-September. The flower is small $2-5 \mathrm{~cm}$ white borne solitary on cylindrical stem. Flowers are 1.5-2.5 cm across, with 5 spreading, oblong to obvate leaves. Basal leaves long stalked, blade broadly elliptic, heart shaped, acute $2.5-5 \mathrm{~cm}$. The major chemical constituents are aucubin and catalpol. It is used in treatment of Wounds, cuts, fractures and healing of body ache, headache and eye disorders.

Plantago major belongs to family Plantaginaceae. It is frequently distributed in fringes slopes of grassland and water channels along roadsides. The flowering occurs in month of May to July. The leaves are ovate, lanceolate, either round base, indistinctly long stalks with dentate margin and entirely covered by small hairs. The Spikes are 10-30 $\mathrm{cm}$ long; arise at centre of leaf base with densely arranged flowers on half of the total spike length. The major chemical constituents are aucubin, catalpol, baicalin and scutellerein. It is used for curing urinary disorders, hypertensive, inflammation activity, diarrhea to improve eyesight and antimicrobial activity.

Podophyllum hexandrum belongs to family Berberidaceae. It is found in cultivated and 
dense sloppy and grass rich vegetation. Reproductive phase occurs from May to Mid July. This perennial herb has stem modified into underground rhizomes. Leaves two, 10$25 \mathrm{~cm}$, deeply cut into 3 ovate toothed lobes. Flowers solitary, terminal white or pink, cup shaped. Fruits are pulpy berry type, scarlet or reddish in colour, less in number with large size. The seeds are red or orange depending upon the phase of development. The major chemical constituents are podophyllin. The entire plant is used for gynecological disease, improves lung and blood circulation and quite useful against altitude sickness.

Potentilla atrosanguinea belong to family Rosaceae. It is commonly native to mountain slopes at lower elevations in the Himalayan ranges. The flowering season occurs in June to August. The perennial spreading herb grows up to $18-30 \mathrm{~cm}$. Specific epithet comes from the Latin word atrosanguineus meaning dark blood red in reference to the flower color. The major chemical constituent is potifulgene. It is used for the treatment of diarrhea and diabetes

Ribes orientale belongs to the family Grossulariaceae. The plants are commonly found on moist as well as dry slopes along road side. Flowering season occurs during May-September. The deciduous shrub is branched, erect and thorny attain up to 2-6 m in height. Branches are sticky abundance with glands. The leaves are3-5 lobed rounded, reniform, 1.2- $3.8 \mathrm{~cm}$ broad, with minute sticky glandular hairs scattered, throughout the surface. The plant possesses minute unisexual, Greenish-purple flowers with racemes type inflorescence. Bracts may be longer than pedicels, linear or somewhat lanceolate in shape with $2-5 \mathrm{~mm}$ length. Calyx tube is hairy, ovate, spreading, hairy, lobed, glandular, and longer than stamens and petals. Petals are small, obovate, clawed 4-5 in number. Stamens are 4-5 and longer as compared to petals. The berries are round, small, sour sparsely hair cover with thin epicarp. The pigmentation of fruits varies from orange to deep red colour with extending season. The seeds are numerous. It is recommended for curing gastric trouble and diuretic agent. The berries are very rich in vitamin-C. It is also used in treatment of spasmodic vomiting and dysentery and acts as excellent purgative.

Saussurea costus belongs to family Asteraceae. This Perennial herb is now cultivated as field crop in most regions as cash crop. Reproductive cycle occurs during May-August. Stems are erect, unbranced, hairy and tall having 2-2.5 m. The leaves are large, cauline, pinnate and triangular in shape. Head sessile, purple, dense or axillary, rounded, terminal and in clusters. Receptacle are small, bristles, long, purple bracts and hairy when young. Fruits are achenes, long, compressed with scanty outgrowth glaborous, merely oblong or round, with thickened margins. Pappus is brown, deciduous and all feathery. The chemical constituents are Saussurine, Saussareamines A, B and C. It is used for curing nausea, scabies, epilepsy, hysteria and acts as an anti-arthritic, antiseptic, aphrodisiac, astringent, diaphoretic, deodorant, disinfectant, emmenagogue, spasmodic stimulant, stomachic, tonic and vermifuge. It is also effective in rheumatism, stimulates the brain, promotes urination, and cures diseases of blood, hepatic and renal cures, ear disease and anti-ulcer effects.

Sedum ewersii belongs to family Crassulaceae. It is found abundantly in dry regions preferred rocks, moist stony slopes and high elevated zones of sub alpines. Reproductive cycle occurs during JuneSeptember. The perennial herb plant attains $45-75 \mathrm{~cm}$ height. The stem is spreading with small, erect, thick, bluish green and fleshy leaves 10-35 cm long, round apex that helps to survive in extreme condition. Stem leaves 
usually undivided, opposite or alternate, are entirely or rarely toothed, with slightly waxy and smooth with shiny appearance. Flowers are bisexual and borne to apex of each branch, somewhat light green, but change to purple to dark pink in colour with the passage of season. Pentalobed sepals and petals with ovate or lanceolate. Seeds are ellipsoid, small and numerous. The major chemical constituents are sedamine and sedinine. The plant has a soothing effect and is used for relieving the toothache and burns. It is also used for the treatment of control dysentery.

Thymus serpyllum belongs to family Lamiaceae. The tufted perennial herb shows strong aromatic nature and branched from base having spreading habit. Flowering occurs during July to September. Leaves are sessile and elliptic-oblong in shape. Flowers are reddish or pinkish, crowded in short terminal clusters. The major chemical constituents are thymol, carvacrol, hamazulene, pinene, sabinene, vitexin, apigenin, diosmetin and gentauredin. It is used in treatment of inflammation, stomachache and gastrointestinal problems, persistent fever and to cure bile related diseases. It is also used as bile-expelling, antiinflammatory and hemostatic.

Trifolium repens belongs to family Fabaceae. It is distributed in region of dry as well as moist region of riverside and barren lands. Reproductive cycle occurs during month of May-September.

It is commonly known as white clover and is an herbaceous perennial plant. Herbs have obvate, trifoliate leaves, and minute linear pod. The major chemical constituents are A and B Pinene, p-cymene, B-caryophyllene and geraniol. It is used for curing fever, rheumatic pain and gout.

Verbascum thapsus belong to family Scrophulariaceae. It distributed commonly in wastelands, grasslands and occurs along the cultivated as well as uncultivated fields. Reproductive cycle occurs during MaySeptember. A very distinctive plant species having an erect, unbranched leafy stem 1-2 m tall. Leaves are light green or grey, may appear wooly, soft oblanceolate in shape present at lower regions or basal portion covering the base. The flowers are abundant, yellow, borne in a slender woolly spike and completely cover the spike at the end of the flowering season. The major chemical constituents are neolignan and spermine. It is used for the treatment of diarrhoea spasmodic coughs, inflammatory diseases, and migraine headaches and asthma.

\section{Results and Discussion}

Out of 31 medicinal plants documented from the valley, the diversity of most of these species is endemic and restricted to certain region. The population of some species favors the distribution of other species in mystifying way i: e abundance of Podophyllum hexandrum species is supported by the diversity of Betula utilis, Arnebia by Elymus semicostatus, Impatians by Mentha longifolia etc. (Figure 2). The major threat is to the plants whose flowers, stem and underground root portion is used commercially in herbal formulation. The families dominated in the region were Apiaceae, Asteraceae, Rosaceae, Scrophulaiaceae, Gentianaceae and Polygonaceae (Figure 1). The plants species are mostly perennial in habit and shows flowering from May to September. The fruit type is Capsule and Achene in more than 70 \%families but schizocarp berry, pods, nutlets, follicle and dry fruit were also observed in Thymus serphyllum, Ribes alpinum, Potentilla atrosanguinea, sedum ewarsii, Aquilegia fragrans and origanum vulgare respectively (Table 2). The plant species are importants source of various chemical such as Tropane, Emodin, Aloe-emodin, Physcion and Rhein, Cuscutalin and Cuscutin, Vitexin, 
Podophyllin, Aquilegiolide, Plantagin, Varbascoside, Piperazine, Sedamine and sedinine, Aquilegiolide, Avicalurin, Aucubin, Malvallin, Organol, Potifulgene, and Thymol (Table 2). Many threatened plant species (Podophyllum hexandrum, Aconitum heterophyllum, Rhododendron campanulatum, Ephedra gerardiana, Thymus linearis and Potentilla atrosanguinea) were also recorded during exploration. More than 17 types of disease ailment are carried out by amchis in Keylong region (Srivastava and Shukla, 2015; Samant and Pant, 2006; Bhatarai et al., 2014; Uniyal et al., 2002; Jahanger et al., 2013; Vidyarthi et al., 2013). Out of total medicinal plants diversity, 4 were shown anticancerous, antipyretic, controlling bile disorders, spasmodic diseases and diarrhea, 3 for dysentery and hepatic diseases, 2 for neurological, antimicrobial as well as urinary diseases, 7 plants are used for treatment for other ailments such as arthritis, wounds, toothache, muscular pain, vomiting, boils, rheumatism, bleeding and burns (Figure3). Most of the plants studied have already proved their medicinal potential and well documented in literature. These medicinal plants diversity are also used in different medicinal systems such as Unani, Ayurveda and Tibetean medicinal systems. The study illustrates that difference of health facilities lacking in these regions, and still Tibetean communities depends upon local plants for health purposes. Different reconnaissance survey and group discussion with local peoples are used for collecting information. The folk uses of these plants on medicinal value seem to be confined by Tibetan practitioners. The information of all the resources much restricted or inclined to the elder monks above 60 years. While working on current aspects of exploration on utility of medicinal plants, it was found that communities are hesitant to convey information. It is such knowledge that gives recognition to them in their localities, as the way conveying the information is verbal and poor; most of the information has been lost from generation to generation.

In conclusion, it was understood from the survey that the monk communities residing in regions of Lahaul valley have inherited a diverse and concentrated resource of medicinal plants. They still depend upon floristic diversity of local medicinal plants and are attentive about their depletion in native habitats. The documentation on these rich traditional knowledge has offered novel reports from the area. The degradation of these wild plants is also a matter of concern for medicinal practitioners as well as for ecologists. Keeping this viewpoint in mind, the present study on documentation of tribal knowledge from the region where novel information was conserved in form of sacred mythologies related with plants. It also helps in its conservation, led the cushion of new pharmacological values for the betterment of mankind. An approach was made to explore the indigenous flora restricted to mention name localities and its conservation status for future generations. The conservation of rare and endangered species of cold desert by research institutions and state departments through establishment of medicinal park, herbal gardens, ex-situ and in-situ conversation, will be beneficial for overall development of the region and sustainable utilization of these wild resources for the future. The Himalayan region is well known for its valuable herbal wealth since ancient time. Similarly, Himalayan region which seems barren and devoid of vegetation at the first sight is very rich in herbal resources. The present exploration study will help to reveal the potential of local plants in the support of notable traditional knowledge. Wild food plants have already represented as the milestone of the traditional food systems and still proved as a pillar of the local food sovereignty. The medicinal plants play a vital 
role in ancient as well as present time scenario and need to be carefully reevaluated and reconsidered by pharmacologists and medicinal practitioners.

Table.1 Geographical location of area surveyed

\begin{tabular}{|c|c|c|c|c|}
\hline Sr.No. & Area surveyed & Altitude (m) & Latitude & Longitude \\
\hline $\mathbf{1 .}$ & Kardang & 3500 & $32.5632^{\circ} \mathrm{N}$, & $77.0234^{\circ} \mathrm{E}$ \\
\hline $\mathbf{2}$ & Gumrang & 3080 & $32.5417^{\circ} \mathrm{N}$, & $77.0514^{\circ} \mathrm{E}$ \\
\hline $\mathbf{3}$ & Piyukar & 3190 & $32.55629^{\circ} \mathrm{N}$ & $77.0177^{\circ} \mathrm{E}$ \\
\hline $\mathbf{4}$ & Parandas & 3131 & $32.5648^{\circ} \mathrm{N}$ & $77.0255^{\circ} \mathrm{E}$ \\
\hline $\mathbf{5}$ & Nemafed & 3320 & $32.57705^{\circ} \mathrm{N}$ & $77.02202^{\circ} \mathrm{E}$ \\
\hline $\mathbf{6}$ & Bhondla & 3199 & $32.57938^{\circ} \mathrm{N}$ & $77.01677^{\circ} \mathrm{E}$ \\
\hline
\end{tabular}

Table.2 Botanical Names, Family, Habit, fruit type and Active constituents in various plants

\begin{tabular}{|c|c|c|c|c|c|c|}
\hline Botanical Name & $\begin{array}{c}\text { Common } \\
\text { name }\end{array}$ & Family & Habit & $\begin{array}{c}\text { Flower } \\
\text { season }\end{array}$ & Fruit type & $\begin{array}{c}\text { Active } \\
\text { Constituent }\end{array}$ \\
\hline $\begin{array}{l}\text { Achillea } \\
\text { millefolium }\end{array}$ & Gandrain & Asteraceae & Perennial & July-Aug & Cypsela & Achilleine \\
\hline Bistorta vivipara & Ban-mundu & Polygonaceae & Perennial & July-Sept & Capsule/pod & Viviparum \\
\hline $\begin{array}{l}\text { Thymus } \\
\text { serphyllum }\end{array}$ & Tumbrak & Lamiaceae & Perennial & July- Sept & Schizocarp & Thymol \\
\hline $\begin{array}{l}\text { Ephedra } \\
\text { gerardiana }\end{array}$ & Somlata & Ephedraceae & Perennial & July-Sept & Berry & Ephedrine \\
\hline $\begin{array}{l}\text { Chenopodium } \\
\text { foliosum }\end{array}$ & Garliche & Chenopodeaceae & Annual & May-Aug & Berry & Ascaridole \\
\hline $\begin{array}{l}\text { Anaphalis } \\
\text { tripilinervis }\end{array}$ & $\begin{array}{l}\text { Pearly- } \\
\text { everlasting }\end{array}$ & Asteraceae & Perennial & June- Aug & $\begin{array}{l}\text { Achene } \\
\text { (cypsela) }\end{array}$ & Anaphatol \\
\hline $\begin{array}{l}\text { Aconogonum } \\
\text { alpinum }\end{array}$ & Khapen & Polygonaceae & Perennial & June- Aug & Achene & Astragalin \\
\hline Carum carvi & Kala jira & Apiaceae & Annual & July- Sept & Achenes & Carvone \\
\hline Rheum australe & Archo & Poiygonaceace & Perennial & May-Sept & Achenes & $\begin{array}{l}\text { Emodin, Aloe- } \\
\text { emodin, } \\
\text { Physcion and } \\
\text { Rhein }\end{array}$ \\
\hline $\begin{array}{l}\text { Rhododendron } \\
\text { campanulatum }\end{array}$ & Chimura & Ericaceae & Perennial & April-Oct & Capsules & Campanulin \\
\hline Rosa webbiana & Jangli gulab & Rosaceae & Perennial & june-Sept & Capsule & Geraniol \\
\hline $\begin{array}{l}\text { Cuscuta } \\
\text { europeana }\end{array}$ & Amarvel & Cuscutaceae & Annual & June-Sept & Capsule & $\begin{array}{l}\text { Cuscutalin and } \\
\text { Cuscutin }\end{array}$ \\
\hline Trifolium repens & Laung & Papilionaceae & Perennial & May-Sep & Pods & Formononetin \\
\hline Oxyria digyna & Suma & Polygonaceae & Perennial & May-Oct & Nuts & Vitexin \\
\hline Platango major & Plantain & Plantaginaceae & $\begin{array}{l}\text { Perennial } \\
\text { herb }\end{array}$ & Aug-Oct & Capsules & Plantagin \\
\hline
\end{tabular}




\begin{tabular}{|c|c|c|c|c|c|c|}
\hline $\begin{array}{l}\text { Aconitum } \\
\text { heterophyllum }\end{array}$ & Atees & Ranunculaceae & Perennial & June-Sept & Capsules & Aconite \\
\hline $\begin{array}{l}\text { Aquilegia } \\
\text { fragrans }\end{array}$ & Columbine & Ranunculaceae & Perennial & June-Sept & Follicles & Aquilegiolide \\
\hline $\begin{array}{l}\text { Astragallus } \\
\text { candolleanus }\end{array}$ & Milkvetch & Fabaceae & $\begin{array}{l}\text { Perennial } \\
\text { herb to } \\
\text { subshrub }\end{array}$ & May-Aug & Capsules & Asparagines \\
\hline Malva neglecta & Sonchala & Malvaceae & $\begin{array}{l}\text { Annual or } \\
\text { Biennial }\end{array}$ & May-Oct & Dry fruit & Malvallin \\
\hline $\begin{array}{l}\text { Podophyllum } \\
\text { hexandrum }\end{array}$ & Ban-kakdi & Berberidaceae & Perennial & May-Aug & Berry & Podophyllin \\
\hline $\begin{array}{l}\text { Parnassia } \\
\text { nubicolla }\end{array}$ & $\begin{array}{l}\text { Himalayan } \\
\text { bog star }\end{array}$ & Saxifragaceae & Annual & July-Oct & Capsule & Piperazine \\
\hline Sedum ewersii & Patharchatta & Crassulaceae & Perennial & June-Sep & Follicles & $\begin{array}{l}\text { Sedamine and } \\
\text { sedinine }\end{array}$ \\
\hline $\begin{array}{l}\text { Verbascum } \\
\text { thapsis }\end{array}$ & $\begin{array}{l}\text { Jangli } \\
\text { tambaccu }\end{array}$ & Scrophulaiaceae & perennial & May-Sep & Capsule & Varbascoside \\
\hline $\begin{array}{l}\text { Aconogonum } \\
\text { alpinum }\end{array}$ & Knotweed & Polygonaceae & $\begin{array}{l}\text { Perennial } \\
\text { herb }\end{array}$ & June-Aug & Achenes & Avicalurin \\
\hline $\begin{array}{l}\text { Euphrasia } \\
\text { officinalis }\end{array}$ & Eye bright & Scrophulaiaceae & Annual & July-Sep & Capsule & Aucubin \\
\hline Origanum vulgare & Oregano & Lamiaceae & $\begin{array}{l}\text { Perennial } \\
\text { herb }\end{array}$ & July-Aug & Dry fruit & Organol \\
\hline Ribes alpinum & Currant & Grossulariaceae & $\begin{array}{l}\text { Perennial } \\
\text { shrub }\end{array}$ & May-June & Berry & $\begin{array}{l}\text { Malonylrhamn } \\
\text { osides }\end{array}$ \\
\hline $\begin{array}{l}\text { Potentilla } \\
\text { atrosanguinea }\end{array}$ & Cinquefoils & Rosaceae & Perennial & May-Aug & Nutlets & Potifulgene \\
\hline Ribes orientale & Nayangada & Grossulariaceae & $\begin{array}{l}\text { Perennial } \\
\text { shrub }\end{array}$ & May-Sept & Berry & Rutin \\
\hline Thymus linearis & $\begin{array}{l}\text { Jangali } \\
\text { ajwain }\end{array}$ & Lamiaceae & Perennial & May -Sept & Nutlet & Thymol \\
\hline $\begin{array}{l}\text { Physoschlaina } \\
\text { praealta }\end{array}$ & Langthang & Solanaceae & $\begin{array}{l}\text { Perenial } \\
\text { herb }\end{array}$ & June-july & Capsule & Tropane \\
\hline
\end{tabular}

Note*: The information in the above table regarding chemical constituents is confined with literature (Srivastava and Shukla, 2015; Samant and Pant, 2006; Bhattarai et al., 2014; Uniyal et al., 2002; Jahanger et al., 2013; Vidyarthi et al., 2013). 
Figure.1 Number of plants used for treating various diseases

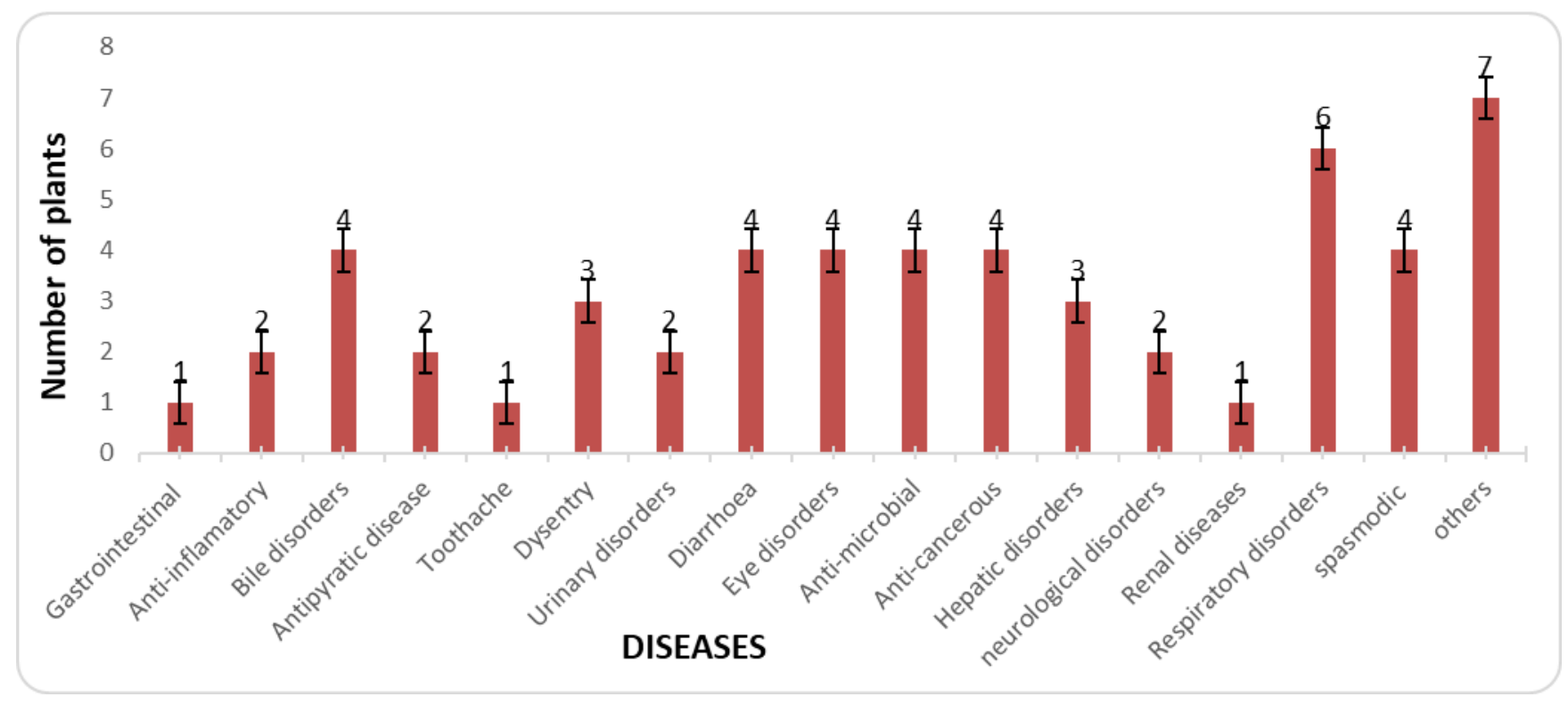

Figure.2 Map of surveyed area at Lahaul regions of Himachal Pradesh
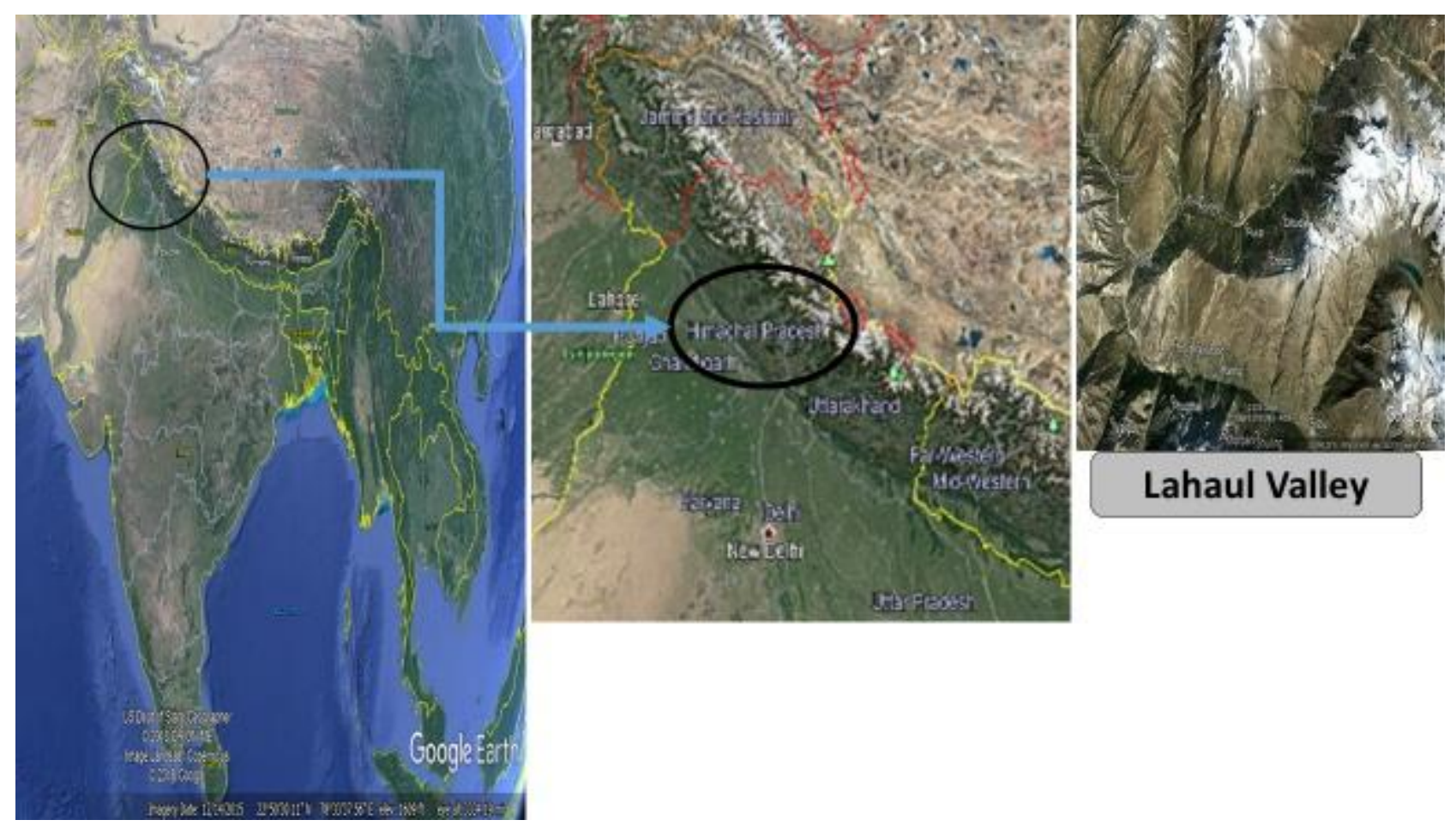
Figure3: List of selected medicinal plants collected during survey in month of July - September on pattan valley, District Lahaul-Spiti, Himachal Pradesh (2016-17): A. Aconogonum alpinum B. Oxyria digyna C. Pterocarpus indica D. Bistorta vivipara E. Aquilegia fragrans $F$. Anaphalis triplivens G. Thymus serpyllum H. Ephedra geradiana I. Tussilago farfara J. Chenopodium foliosum K. Mentha longifolia L. Ribes alpestris M. Origanum vulgare N. Euphrasia officinalis O. Hippophae rhamnoides.

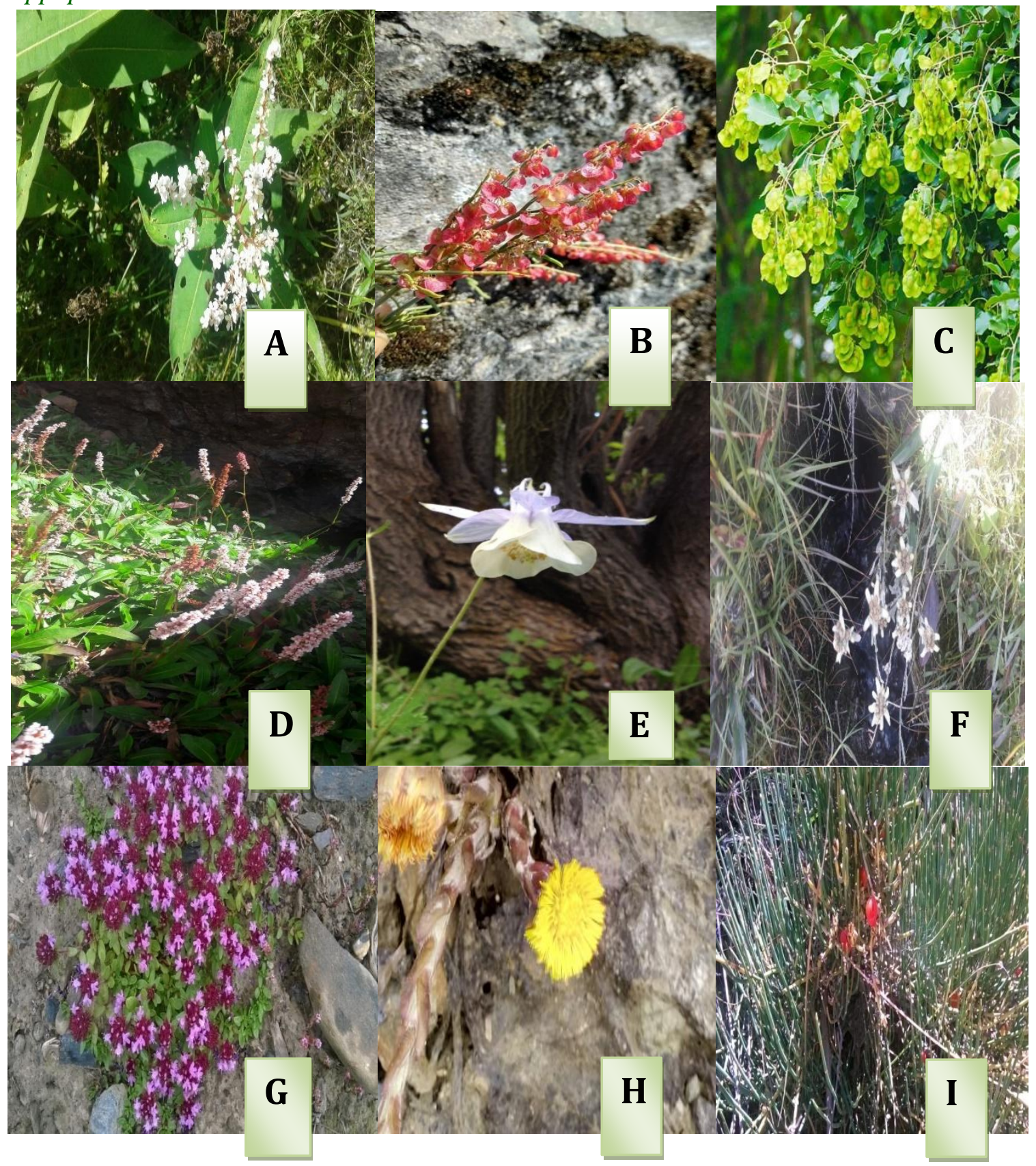




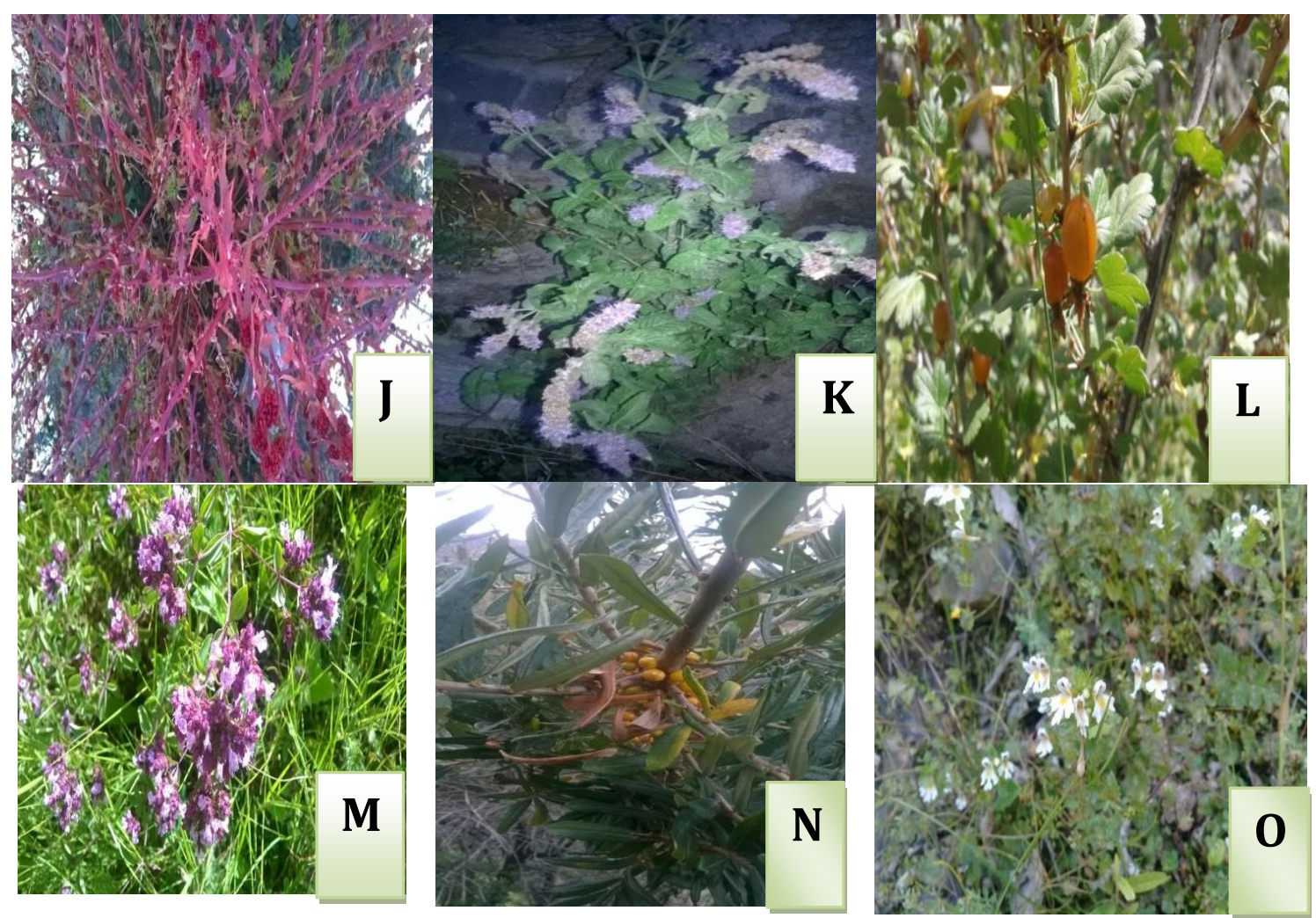

\section{References}

Adhikari, B., Kumar, A., Mitra, M., and Rawat, G. 2016. Flora of Niti Valley: a cold arid region of Nanda Devi Biosphere Reserve, Western Himalaya, India. Check List. 12(1): 1824.

Aswal, B.S., and Mehrotra, B.N. 1994. Flora of Lahaul Spiti (A Cold Desert in North-West Himalaya).

Ballabh, B., Chaurasia, O.P., Ahmed, Z., and Singh, S.B. 2008. Medicinal plants of cold desert Ladakh used in the treatment of stomach disorders. Journal of Ethnopharmacology. 118(2): 331-339.

Bhattarai P, PandeyB, Gautam R, and Chhetri R. 2014. Ecology and Conservation Status of Threatened Orchid Dactylorhiza hatagirea (D. Don) Soo in Manaslu Conservation Area, Central Nepal. American Journal of Plant Science. 5: 3483-3491.

Chandrasekar, K., and Srivastava, S.K. 2009.
Flora of Pin Valley National Park, Himachal Pradesh. Botanical Survey of India. Kolkata.

Chaurasia, O.P., and Singh, B. Cold desert flora (I-V) Field Research Laboratory. Leh- Ladakh.

DESIDOC, Delhi. 1996-2001.

Jahangeer, A.B., Munesh, K., and Rainer, W.B., 2013. Ecological status and traditional knowledge of medicinal plants in Kedarnath Wildlife Sanctuary of Garhwal Himalaya. Indian Journal of Ethnobiology and Ethnomedicine.9:1.

Kala, C.P. 2005. Health traditions of Buddhist community and role of Amchis in transHimalayan region of India. Current Science.89 (8): 1331-1338.

Kanta, Sharma, I.P., and Shiekh, M.A. 2018. Ethnobotanical studies on medicinal plants of Langate area, Kupwara, Jammu and Kashmir, India, Chandra. Journalof Medicinal Plants Studies. 6(2): 94-97. 
Kaul, M.K. 1997. Medicinal plants of Kashmir and Ladakh, (Temperate and cold Arid Himalaya) Indus publishing company, New Delhi.

Kumar, A., Mitra, M., Adhikari, B.S., and Rawat, G.S. 2013. Additions to plant wealth of Nanda Devi Biosphere Reserve, Western Himalaya. The Indian Forester.139(10): 959-961.

Nautiyal, S., Maikhuri, R.K., Rao, K.S., and Saxena, K.G. 2001. Medicinal Plant Resources in Nanda Devi Biosphere Reserve in the Central Himalayas. Journal of Herbs, Spices and Medicinal Plants. 8(4): 47-64.

Samant, S.S., and Pant, S. 2006. Diversity, Distribution Pattern and Conservation Status of the Plants Used in Liver Diseases/Ailments in Indian Himalayan Region. Journal of Mountain Science. 3(1): 28-47.
Srivastava S.K. and Shukla A.N. 2015. Flora of Cold Desert of Western Himalaya. Vol II. Botanical Survey of India, Kolkata.

Uniyal, S.K., Awasthi, A, and Rawat, G.S. 2002. Current status and distribution of commercially exploited medicinal and aromatic plants in upper Gori Valley, Kumaon Himalaya, Uttaranchal. Current Science. 82: 1246-1252.

Vidyarthi, S., Samant, S.S., and Sharma, P. 2013. Traditional and indigenous uses of medicinal plants by local residents in Himachal Pradesh, North Western Himalaya. India. International Journal of Biodiversity Science, Ecosystem Services and Management. 9 (3): 185200.

\section{How to cite this article:}

Antul Kumar, Anuj Choudhary and Harmanjot Kaur. 2020. Diversity of Wild Medicinal Flora in Lahaul Valley of Himachal Pradesh, India. Int.J.Curr.Microbiol.App.Sci. 9(07): 48-62. doi: https://doi.org/10.20546/ijcmas.2020.907.006 